Article

\title{
Importance of Magmatic Water Content and Oxidation State for Porphyry-Style Au Mineralization: An Example from the Giant Beiya $\mathrm{Au}$ Deposit, SW China
}

\author{
Xinshang Bao, Liqiang Yang *, Wenyan He and Xue Gao \\ Affiliation State Key Laboratory of Geological Processes and Mineral Resources, China University of \\ Geosciences, Beijing 100083, China; baoxinshang@163.com (X.B.); wyhe@cugb.edu.cn (W.H.); \\ xuegao@cugb.edu.cn (X.G.) \\ * Correspondence: lqyang@cugb.edu.cn; Tel.: +86-(010)-82321937
}

Received: 26 July 2018; Accepted: 6 October 2018; Published: 10 October 2018

check for updates

\begin{abstract}
The Beiya Au deposit is the largest Cenozoic Au deposit in the Jinshajiang-Ailaoshan porphyry metallogenic belt. Numerous studies document that high water content and $\mathrm{fO}_{2}$ are vital factors for the generation of $\mathrm{Au}$ mineralization. In this belt, only the Wandongshan and Hongnitang districts are considered to be of economic importance, while the other districts, such as Bailiancun, are barren. So in order to reveal the importance of water content and oxidation state for Beiya porphyry-style Au mineralization, the amphiboles and zircons compositions are used to evaluate the physicochemical conditions (e.g., pressure, temperature, $f \mathrm{O}_{2}$, and water content) of the Wandongshan ore-fertile porphyries and Bailiancun ore-barren porphyries observed in the Beiya Au deposit. The results show that the water content of the Wandongshan parent magma $(\leq 4.11 \pm 0.4 \mathrm{wt} \%)$ are slightly higher than those of the parent magma at Bailiancun $(\leq 3.91 \pm 0.4 \mathrm{wt} \%)$, while the emplacement pressure of the Wandongshan parent magma (31.5-68.6 MPa) is much lower than that of the parent magma at Bailiancun (142.3-192.8 MPa), indicating that the Wandongshan magma reached water saturation earlier. In addition, the Wandongshan porphyries crystallized from more oxidized magma (average of $\triangle \mathrm{FMQ}=+3.5$ ) with an average temperature of $778^{\circ} \mathrm{C}$ compared to the Bailiancun porphyries (average of $\triangle \mathrm{FMQ}=+1.5$ ) with a mean magmatic temperature of $770^{\circ} \mathrm{C}$. The $\mathrm{Ce}^{4+} / \mathrm{Ce}^{3+}$ ratio of zircon in the Wandongshan ore-related intrusions (average $\mathrm{Ce}^{4+} / \mathrm{Ce}^{3+}$ of 62.00) is much higher than that of the Bailiancun barren porphyries (average $\mathrm{Ce}^{4+} / \mathrm{Ce}^{3+}$ of 23.15), which further confirmed Wandongshan ore-related magma is more oxidized than the Bailiancun barren magma. Therefore, melts that are more enriched in water and with a high oxidation state will be more fertile to form an economic porphyry-style Au system.
\end{abstract}

Keywords: oxidation state; hydrous melts; constraints on mineralization; Beiya Au deposit; SW China

\section{Introduction}

Porphyry systems supply three-quarters of the world's $\mathrm{Cu}$ and one-fifth of the world's $\mathrm{Au}$ resources [1]. It's widely accepted that high water content $(>4 \mathrm{wt} \%)[2,3]$ and a high oxidation state $(>\mathrm{FMQ}+1.3-2)[4,5]$ of the magma are critical factors for the generation of $\mathrm{Cu}-\mathrm{Au}$ mineralization. The solubility of $\mathrm{Cu}$ and $\mathrm{Au}$ in hydrous silicate melts was proven to be affected by the amount and proportion of dissolved sulfate and sulfide in S-bearing magma, whereas $f \mathrm{O}_{2}$ controls the speciation of sulfur [5-7]. Under high $f \mathrm{O}_{2}$ conditions, the majority of sulfur exists as $\mathrm{SO}_{2}$ or $\mathrm{SO}_{4}{ }^{2-}$ with very low concentrations of $\mathrm{S}^{2-}$ in a magma [6], which prevents saturation of immiscible $\mathrm{Cu}$ - and $\mathrm{Au}$-sulfides during magmatic fractionation [4,6]. High magmatic water content of the magma $\left(\mathrm{H}_{2} \mathrm{O}>4 \mathrm{wt} \%\right)$ is 
also an essential factor for the generation of porphyry $\mathrm{Cu}-\mathrm{Au}$ deposits [8-11]. The high water content of the magma not only promotes magmatic water reaching saturation earlier [10], but also increases the partitioning of $\mathrm{Au}$ from melt to aqueous volatile phases [12,13]. However, the impacts of water content and magma oxidation state on Au mineralization are still debated.

The Beiya Au deposit is the largest Cenozoic Au deposit in the Jinshajiang-Ailaoshan porphyry metallogenic belt [14,15], with proven Au reserves of more than $377 \mathrm{t}$, and by-products of $\mathrm{Cu}, \mathrm{Fe}, \mathrm{Ag}, \mathrm{Pb}$, and Zn [16]. Numerous studies have documented the petrography, chronology, geochemistry, and fluid inclusions of the porphyry intrusion from the Beiya Au deposit [17-19]. These studies have revealed that the monzogranite porphyry is directly related to skarn formation and mineralization $[17,18]$. The ore-forming monzogranite porphyry at Wandongshan is water-rich $[13,19]$ and has a high oxidation state $[20,21]$. However, systematic studies on the relationship of water content and oxidation state on $\mathrm{Au}$ mineralization at Beiya are lacking. Comparing the water content and oxidation state of the mineralized and barren porphyries in the Beiya Au deposit is important for understanding the importance of water content and oxidation state for Beiya porphyry-style Au mineralization.

Both the monzogranite porphyries at Wandongshan and Bailiancun contain amphibole phenocrysts [22], even though the Wandongshan is considered to be of economic importance and the Bailiancun is barren [22-24]. Thus, we choose the Wandongshan and Bailiancun as the focus of our study. We investigated the mineralogical and geochemical characteristics of the amphiboles and zircons from the Wandongshan and Bailiancun monzogranite porphyries. In order to determine the relationship of $f_{2}$ and water content on $\mathrm{Au}$ mineralization, we compared the water content and oxidation state of the mineralized Wandongshan ore-bearing and Bailiancun barren monzogranite porphyries.

\section{Geological Setting}

The Sanjiang (Nujiang-Lancangjiang-Jinshajiang) region is an important part of the Tethys tectonic domain, located in Southwestern China [25,26]. The Jinshajiang-Ailaoshan suture zone is located in the eastern Himalaya-Tibetan plateau of the Tethyan domain and is bounded by the western Yangtze Craton to the southeast (Figure 1). The regional tectonic evolution includes subduction of the Paleo-Tethyan oceanic slab, and magmatic arc formation followed by arc-continent collision during the Paleozoic-Mesozoic era, and then Indo-Asian continental collision during the Cenozoic [27,28]. The collision between the Indo and Asian continents have caused more than $300 \mathrm{~km}$ of strike-slip movement along the Ailaoshan-Red River shear zone since the Paleocene [29,30]. As a consequence of this strike-slip, lithospheric-scale extension has occurred, causing a set of secondary NNW-trending strike-slip faults and folds, and the emplacement of numerous alkali-rich intrusions along the Jinshajiang suture zone [31-33]. These intrusions form a 2000-km-long and 50- to 80-km-wide alkaline magmatic belt, and are associated with several important porphyry and skarn polymetallic $(\mathrm{Cu}, \mathrm{Au}$, $\mathrm{Mo}, \mathrm{Zn}, \mathrm{Pb}$, and Ag) deposits [34,35] in the Jinshajiang-Ailaoshan metallogenic belt (Figure 1b) [7], from north to south: the Yulong $\mathrm{Cu}$, the Beiya $\mathrm{Au}$, the Machangqing $\mathrm{Cu}-\mathrm{Mo}-\mathrm{Au}$, the Yao'an Au, the Habo Cu-Mo-Au, and the Tongchang $\mathrm{Cu}-\mathrm{Mo}$ deposits.

The Beiya $\mathrm{Au}$ deposit is located in the center of the Jinshajiang-Ailaoshan magmatic belt (Figure 1a), which covers an area of $\sim 800 \mathrm{~km}^{2}$ and is distributed along the limbs of the N-S trending Beiya syncline [16]. The Beiya Au deposit consists of two zones [22,23], with the Bijiashan (BJS), Weiganpo (WGP), and Guogaishan (GGS) ore districts to the east, the Wandongshan (WDS), Hongnitang (HNT), and Jingouba (JGB) ore zones to the west, and the Bailiancun (BLC) occur around the periphery of the Beiya Au deposit (Figure 2). The formation hosting the Wandongshan district are dominated by Permian basalt, Triassic sandstone and limestone, with Quaternary alluvial cover, while the strata hosting the Bailiancun district are mainly Permian basalt and Quaternary alluvial cover. There are abundant Tertiary alkaline porphyry intrusions distributed in the Wandongshan and Bailiancun districts. The Tertiary alkaline porphyry intrusions include monzogranite porphyries, biotite monzogranite porphyries, and lamprophyres (Figure 2a). The monzogranite porphyries 
represent the volumetrically most important igneous rock and are genetically related to the mineralization both at Wandongshan and Bailiancun districts [15,25]. Though the monzogranite porphyries at Wandongshan and Bailiancun districts have similar zircon U-Pb ages ( $36.2 \pm 0.6 \mathrm{Ma}$ and $36.1 \pm 0.15 \mathrm{Ma}$, respectively) $[15,17]$ and the same magma source [22], their mineralization types are different. The Wandongshan monzogranite porphyries form economical porphyry-skarn Fe-Cu-Au mineralization [22-24], while the Bailiancun monzogranite porphyries form hydrothermal $\mathrm{Pb}-\mathrm{Zn}$ veins [22].

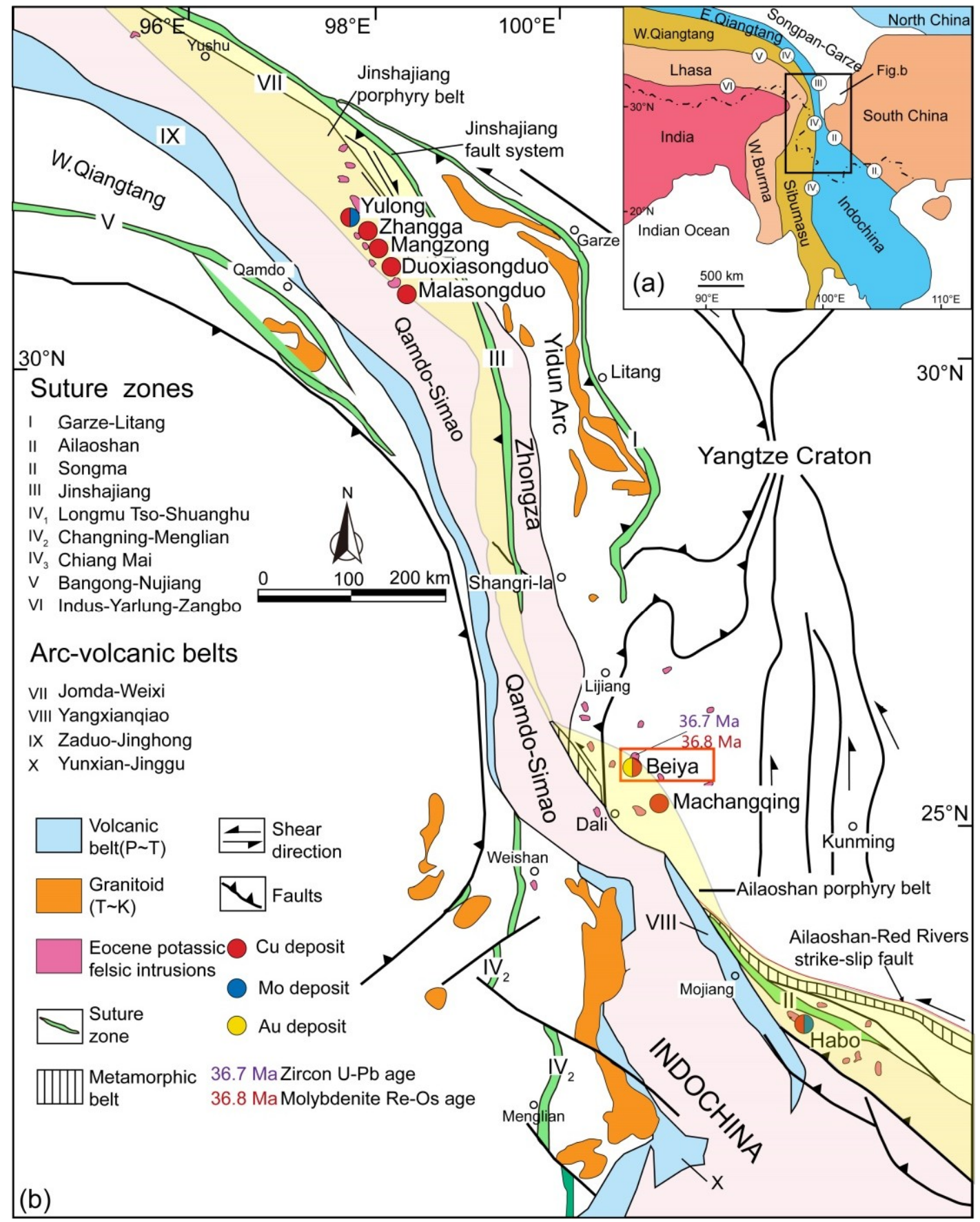

Figure 1. Regional tectonics of the Jinshajiang-Ailaoshan alkaline porphyry belt showing the distribution of Cenozoic deposits [17]. 

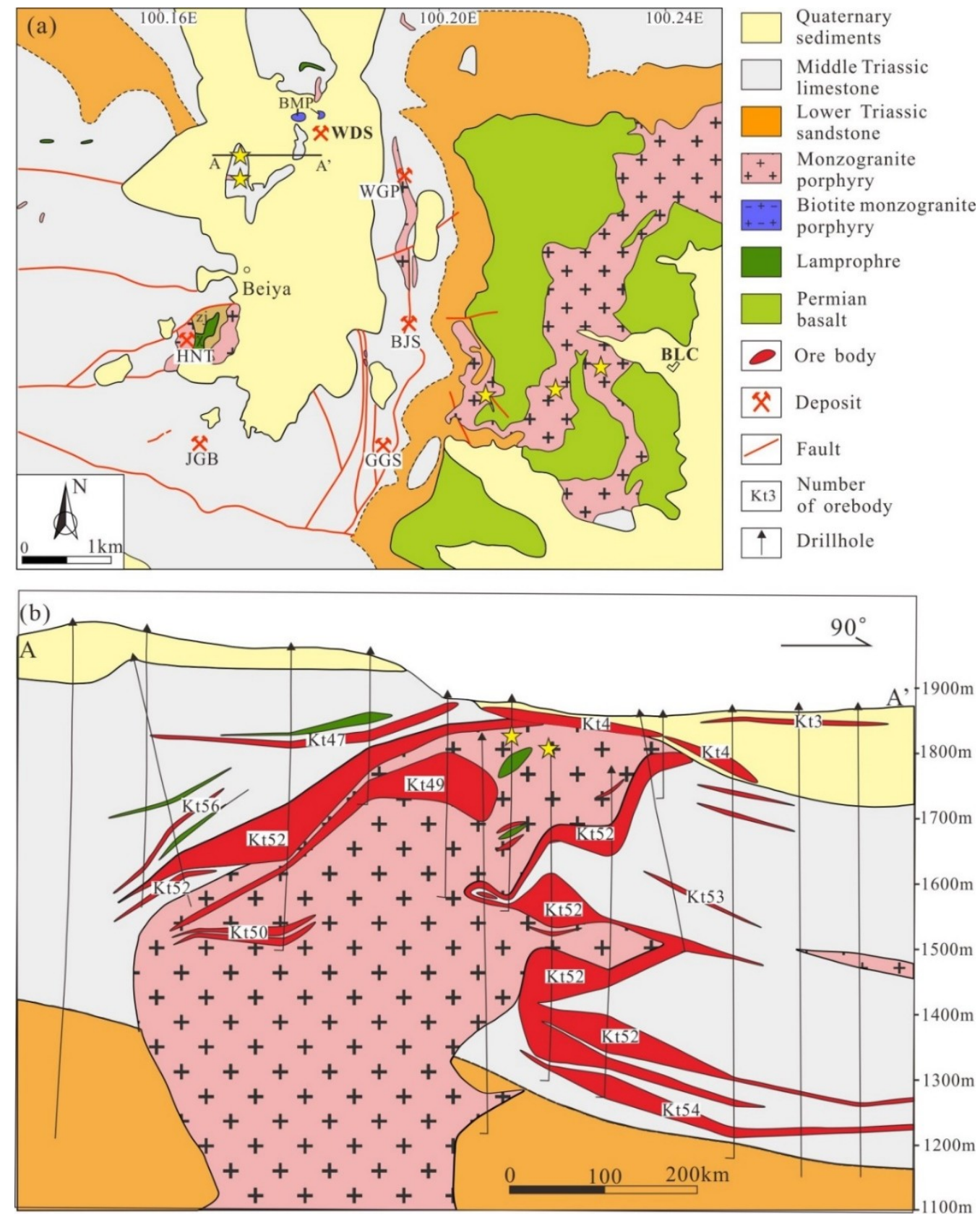

Figure 2. Geology of the Beiya Au deposit (a) and representative crosssection of Wandongshan district showing the location of the skarn ore body (b) [23]. WDS: Wandongshan district; HNT: Hongnitang district; JGB: Jin'gouba district; WGP: Weiganpo district; GGS: Guogaishan district; BJS: Bijiashan district; BLC: Bailiancun district.

\section{Petrography of Alkaline Intrusions}

\subsection{The Wandongshan Monzogranite Porphyry}

The Wandongshan monzogranite porphyry intrusion has a gray-white color and porphyritic textures. Phenocrysts form about $50 \mathrm{vol} \%$ of the rock, and include K-feldspar, plagioclase, quartz, biotite, and minor amphiboles (Table 1). The K-feldspar phenocrysts make up about $5-15$ vol \% and usually have euhedral to subhedral shapes that range in size from 0.2 to $0.5 \mathrm{~mm}$, with occasional Carlsbad twinning (Figure 3a). The plagioclase phenocrysts $(1-5 \mathrm{~mm})$ are mostly euhedral in shape, showing tabular biotite inclusions (Figure 3c). The quartz phenocrysts are irregular, with a circular 
shape. The amphibole phenocrysts are mostly euhedral, usually measuring $0.4 \mathrm{~mm}$ in size (Figure 3b). The groundmass comprises fine-grained feldspar and quartz. The accessory minerals are apatite, magnetite, titanite, and zircon. The mineralization is dominated by pyrite and chalcopyrite within quartz veins, as well as disseminated in the monzogranite.

Table 1. Petrography of the monzogranite porphyry from the Wandongshan and Bailiancun ore districts.

\begin{tabular}{ccccc}
\hline Ore Deposits & Rock Type & Phenocrysts & Groundmass & Accessory \\
\hline Wandongshan & Monzogranite porphyry & $\mathrm{Kfs}+\mathrm{Qtz}+\mathrm{Pl}+\mathrm{Bt}+\mathrm{Amp}$ & $\mathrm{Pl}+\mathrm{Qtz}$ & $\mathrm{Ap}+\mathrm{Zrc}+\mathrm{Ttn}+\mathrm{Mag}$ \\
Bailiancun & Monzogranite porphyry & $\mathrm{Qtz}+\mathrm{Kfs}+\mathrm{Pl}+\mathrm{Amp}$ & $\mathrm{Kfs}+\mathrm{Qtz}+\mathrm{Amp}$ & $\mathrm{Ap}+\mathrm{Zrc}$ \\
\hline
\end{tabular}

Qtz: quartz; Kfs: K-feldspar; Pl: plagioclase; Bt: biotite; Amp: amphibole; Ap: apatite; Zrc: zircon; Ttn: titanite; Mag: magnetite.
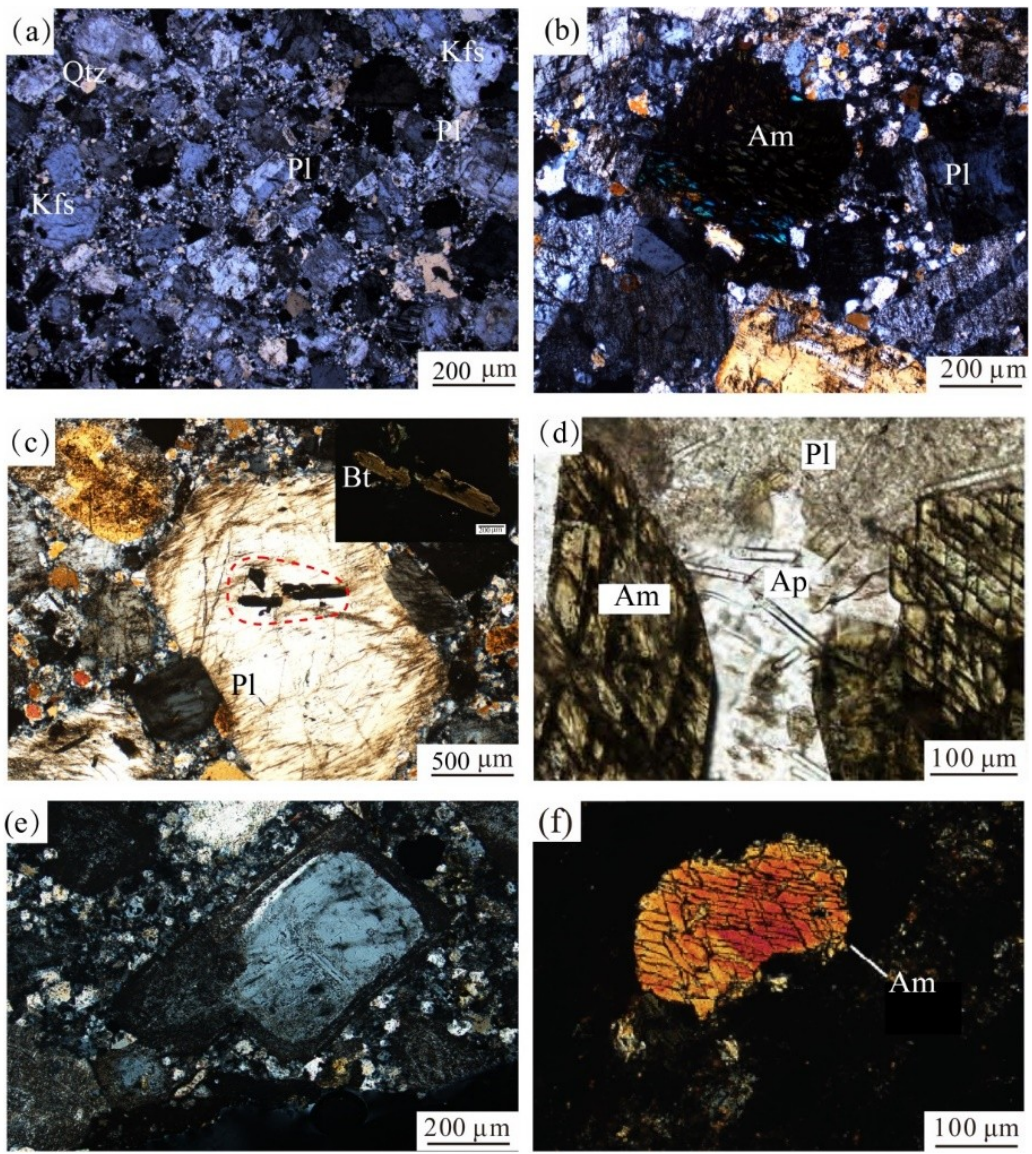

Figure 3. Photomicrographs of the monzogranite porphyries at the Wandongshan and Bailiancun districtdistricts. (a) The monzogranite porphyries at the Wandongshan deposit; cross-polarized light; (b) Plagioclase and amphibole phenocrysts of the Wandongshan monzogranite porphyries; cross-polarized light; (c) Biotite is inside the plagioclase; cross-polarized light; (d) Dioritic enclaves from Wangdongshan; cross-polarized light [23]; (e,f) are photographs of monzogranite porphyries at the Bailiancun district; cross-polarized light. Qtz: quartz; Kfs: K-feldspar; Pl: plagioclase; Bt: biotite; Am: amphibole; Ap: apatite.

\subsection{The Bailiancun Monzogranite Porphyry}

The monzogranite porphyry intrusion at the Bailiancun deposit is characterized by porphyritic texture. Phenocrysts consist of K-feldspar, quartz, plagioclase, and amphibole. The groundmass includes K-feldspar, quartz, and amphiboles (Table 1). The accessory minerals are dominated by apatite and zircon. The K-feldspar phenocrysts make up about $30 \mathrm{vol} \%$ with a euhedral to subhedral 
habitus, and measuring $0.4 \mathrm{~mm}$ in size (Figure 3e). The quartz phenocrysts have subrounded circular shapes. The plagioclase phenocrysts account for $25 \mathrm{vol} \%$ and are mostly euhedral. The amphibole phenocrysts are small $(0.3 \mathrm{~mm})$, with euhedral shapes (Figure $3 \mathrm{f})$.

\section{Analytical Methods and Results}

\subsection{Analytical Methods}

Electron microprobe analysis was conducted on amphiboles using a JEOL JXA-8800 Superprobe at the Institute of Mineral Resources, Chinese Academy of Geological Sciences. The microprobe was operated at an accelerating voltage of $15 \mathrm{kV}$, a beam current of $20 \mathrm{nA}$, and a beam size of $5 \mu \mathrm{m}$. Matrix corrections were performed using the ZAF correction program supplied by the instrument manufacturer. Chemical compositions of amphiboles can be used to evaluate the physicochemical conditions (e.g., pressure, temperature, $f \mathrm{O}_{2}$, and water content) of the parental magma from which the amphibole crystallized [25,36,37].

Zircon trace elements were determined by laser ablation inductively coupled plasma mass spectrometry (LA-ICP-MS) at the Key Laboratory of Crust-Mantle Materials and Environments, Chinese Academy of Sciences (CAS), Hefei. The LA-ICP-MS analyses used a Finnigan Neptune MC-IPS-MS with a high-performance interface coupled with a New-Wave UP-213nm Nd: YAG UV laser. The diameter of the laser ablation pit was $45 \mu \mathrm{m}$ and the mean power output was $4 \mathrm{~W}$. Signal and background measuring durations were about 70 and $40 \mathrm{~s}$, respectively. Further analytical details are given in Liu et al. [38]. Zircon is a widespread accessory mineral that retains its primary chemical and isotope compositions from the time of crystallization [39], which means that the magma oxygen state during crystallization can be recorded by the zircon composition. Zircon solubility is mainly controlled by the temperature and major oxide concentrations of the magma [40]. Titanium exists as $\mathrm{Zr}^{4+}$ and $\mathrm{Si}^{4+}$ isotopes, so the Ti content are controlled by the temperature of the zircon crystallization [41-43]. This study uses the Ti content of the zircon crystals in zircon-saturated melts to estimate the temperature of the melt $(\log (\mathrm{Ti})=6.01 \pm 0.03-(5080 \pm 30) / \mathrm{T}(\mathrm{K}))[42]$.

\subsection{Mineral Chemistry}

\subsubsection{Amphibole Compositions}

Major element compositions and chemistry of amphibole from the monzogranite porphyry at Wandongshan and Bailiancun districts are reported in Supplementary Materials, Table S1.

The amphiboles from the Wandongshan ore deposit are characterized by high $\mathrm{Mg}(\mathrm{MgO}=$ 12.46-14.58 wt \%), high $\mathrm{Ca}(\mathrm{CaO}=10.50-12.31 \mathrm{wt} \%)$, high $\mathrm{Fe}(\mathrm{FeO}=13.61-16.29 \mathrm{wt} \%)$, but low $\mathrm{K}\left(\mathrm{K}_{2} \mathrm{O}=0.33-0.94 \mathrm{wt} \%\right)$ and $\mathrm{Na}\left(\mathrm{Na}_{2} \mathrm{O}=0.55-2.18 \mathrm{wt} \%\right)$ content (Table S1). Compared to the Wandongshan amphiboles, the Bailiancun amphiboles are characterized by lower content of $\mathrm{Mg}(\mathrm{MgO}$ $=9.57-9.90 \mathrm{wt} \%)$ and $\mathrm{Ca}(\mathrm{CaO}=9.54-10.85 \mathrm{wt} \%)$, higher content of $\mathrm{Fe}(\mathrm{FeO}=20.20-21.16 \mathrm{wt} \%)$ and $\mathrm{K}\left(\mathrm{K}_{2} \mathrm{O}=1.22-1.44 \mathrm{wt} \%\right)$. The amphiboles from the Wandongshan porphyry are all edenites (Figure 4a) with high $\mathrm{Mg} /\left(\mathrm{Mg}+\mathrm{Fe}^{2+}\right)$ ratios (0.67-0.79) based on the classification of Leake et al. [41], whereas the amphiboles from the Bailiancun porphyry are all silicic edenites with low $\mathrm{Mg} /\left(\mathrm{Mg}+\mathrm{Fe}^{2+}\right)$ ratios (0.50-0.52; Table S1).

The emplacement pressure of the parental magma at Wandongshan and Bailiancun can be estimated using the Al-in-amphibole geobarometer $[25,36]$. These results show that the emplacement pressures of Wandongshan porphyries range from $31.5 \mathrm{MPa}$ to $68.6 \mathrm{MPa}$, which corresponds to a paleodepth of 1.2-2.4 km (average $1.8 \mathrm{~km}$ ) under lithostatic pressure (Table 2) [36]. In contrast, the emplacement pressures of Bailiancun porphyries are significantly higher (142.3-192.8 MPa), which corresponds to a deeper paleodepth of $5.4-7.3 \mathrm{~km}$ (average $6.7 \mathrm{~km}$ ). Furthermore, water content are directly measure by the component of Wandongshan amphiboles $\left(\mathrm{H}_{2} \mathrm{O}_{\text {melt }}=5.215^{[6]}\right.$ $\left.\mathrm{Al}^{*}+12.28\right)$ [25]. These results show that the water content of the Wandongshan parent magma exhibit 
a wider range of $3.05 \pm 0.4 \mathrm{wt} \%$ to $4.11 \pm 0.4 \mathrm{wt} \%$, whereas those of the Bailiancun parent magma have a tight range of $3.46 \pm 0.52 \mathrm{wt} \%$ to $3.91 \pm 0.4 \mathrm{wt} \%$ (Table 2, Figure $4 \mathrm{~b}$ ). Moreover, the amphibole composition is affected by the oxidation state of its parental melt, thus they allow the direct analysis of the oxygen state of their parental magmas [25]. The oxidation state deduced from amphiboles of the Wandongshan porphyry range from $\Delta \mathrm{NNO}+1.00$ to $\Delta \mathrm{NNO}+1.89$ (NNO is the nickel-nickel oxide oxygen buffer), slightly higher than that of the Bailiancun porphyries $(\Delta \mathrm{NNO}+0.39$ to $\Delta \mathrm{NNO}+0.67$, Table S1).
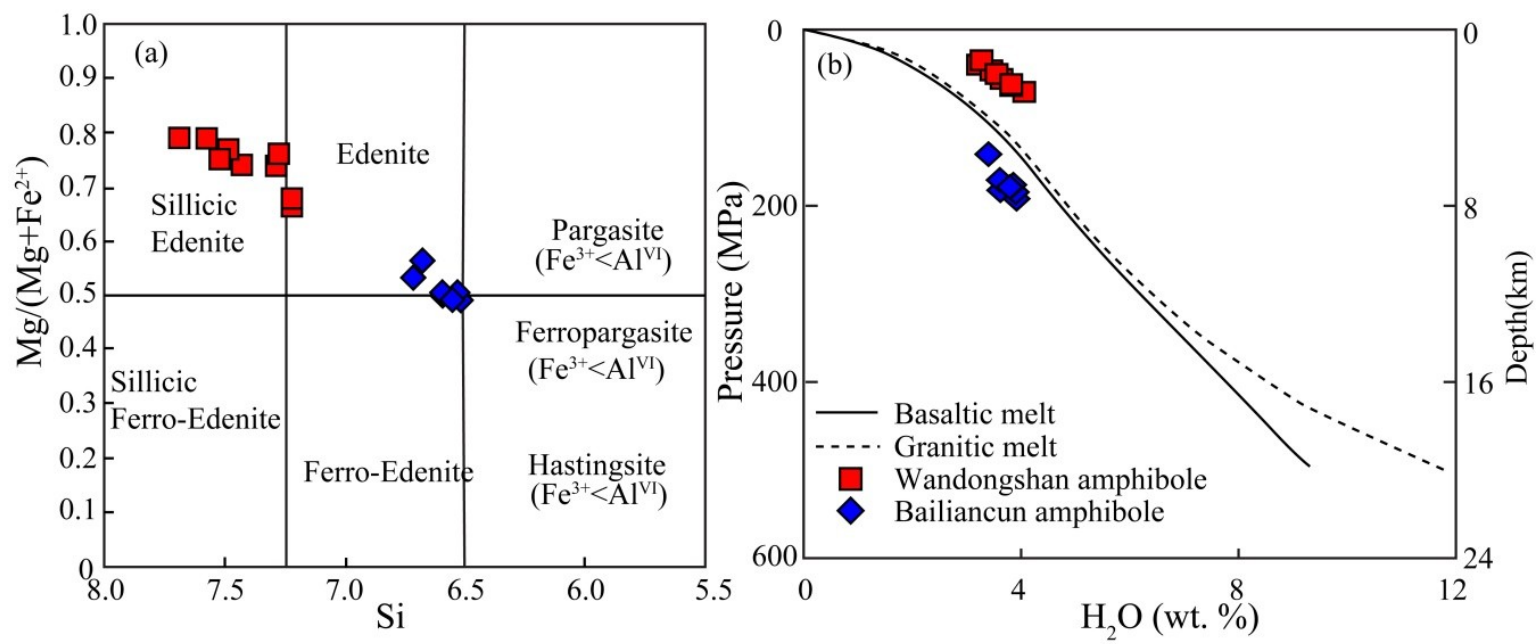

Figure 4. Composition of amphiboles from the Wandongshan and Bailiancun monzogranite porphyries, using the nomenclature of Leake et al. [42] (a), and experimentally determined solubilities of $\mathrm{H}_{2} \mathrm{O}$ in silicate melts as a function of granitic pegmatite pressure (b) [44]. WDS: Wandongshan; BLC: Bailiancun.

Table 2. The water content and oxidation state of the parental magmas from the Wandongshan and Bailiancun districts.

\begin{tabular}{ccccccc}
\hline & \multicolumn{3}{c}{ Amphibole Phenocryst } & \multicolumn{4}{c}{ Zircon } \\
\hline \multirow{2}{*}{ Magmatic Geochemistry } & Pressure (MPa) & Water Content (wt \%) & \multicolumn{4}{c}{ Oxidation State Index } \\
\cline { 4 - 7 } & & & $\Delta$ NNO & $\Delta$ FMQ & Ce $^{\mathbf{4 +}} / \mathbf{C e}^{3+}$ & $\delta$ Ce \\
\hline Wandongshan & $31.5 \sim 68.6$ & $3.05 \sim 4.11$ & +1.62 & +3.5 & $12.1 \sim 144.6$ & $9.25 \sim 203.83$ \\
Bailiancun & $142.3 \sim 192.8$ & $3.46 \sim 3.91$ & +0.5 & +1.5 & $11.5 \sim 39.4$ & $11.42 \sim 53.49$ \\
\hline
\end{tabular}

\subsubsection{Zircon Trace Element Composition}

Zircons from the Wandongshan monzogranite porphyries have $\Sigma$ REE ranging from 149.0 to 1096.6 ppm, LREE/HREE (Low Rare Earth Elements/Heavy Rare Earth Elements) ratios varying from 0.01-0.15 (averaging 0.06), Ti content of $2.83-48.3 \mathrm{ppm}$, Ce anomalies varying from 9.25 to 203.83 (averaging 76.11), and Eu anomalies varying from 0.24 to 0.87 (averaging 0.6). However, zircons from the Bailiancun monzogranite have a lower average LREE/HREE ratio (0.04), average Ce anomaly (30.98), and higher average Eu anomaly (0.7) (Figure 5d, Table S2).

The zircon $\mathrm{Ce}^{4+} / \mathrm{Ce}^{3+}$ ratios (12.1-144.6, averaging 62.00) of the Wandongshan monzogranite porphyry intrusions are much higher than those of the Bailiancun monzogranite porphyry (11.5-39.4, averaging 23.15; Figure 5d). Moreover, the average $\triangle \mathrm{FMQ}$ value of Wandongshan monzogranite porphyry is $\triangle \mathrm{FMQ}+3.5$, slightly higher than that of the Bailiancun monzogranite porphyry $(\triangle \mathrm{FMQ}+$ 1.5; Figure 5a). In addition, the Ti-in zircon temperatures of the Wandongshan monzogranite porphyry intrusions yield a wider range of $670.84-988.42{ }^{\circ} \mathrm{C}$, averaging $778{ }^{\circ} \mathrm{C}$, whereas those of the Beiya porphyry system exhibit a tight range of $680.17-818.53^{\circ} \mathrm{C}$, averaging $770{ }^{\circ} \mathrm{C}$ (Table 2). 

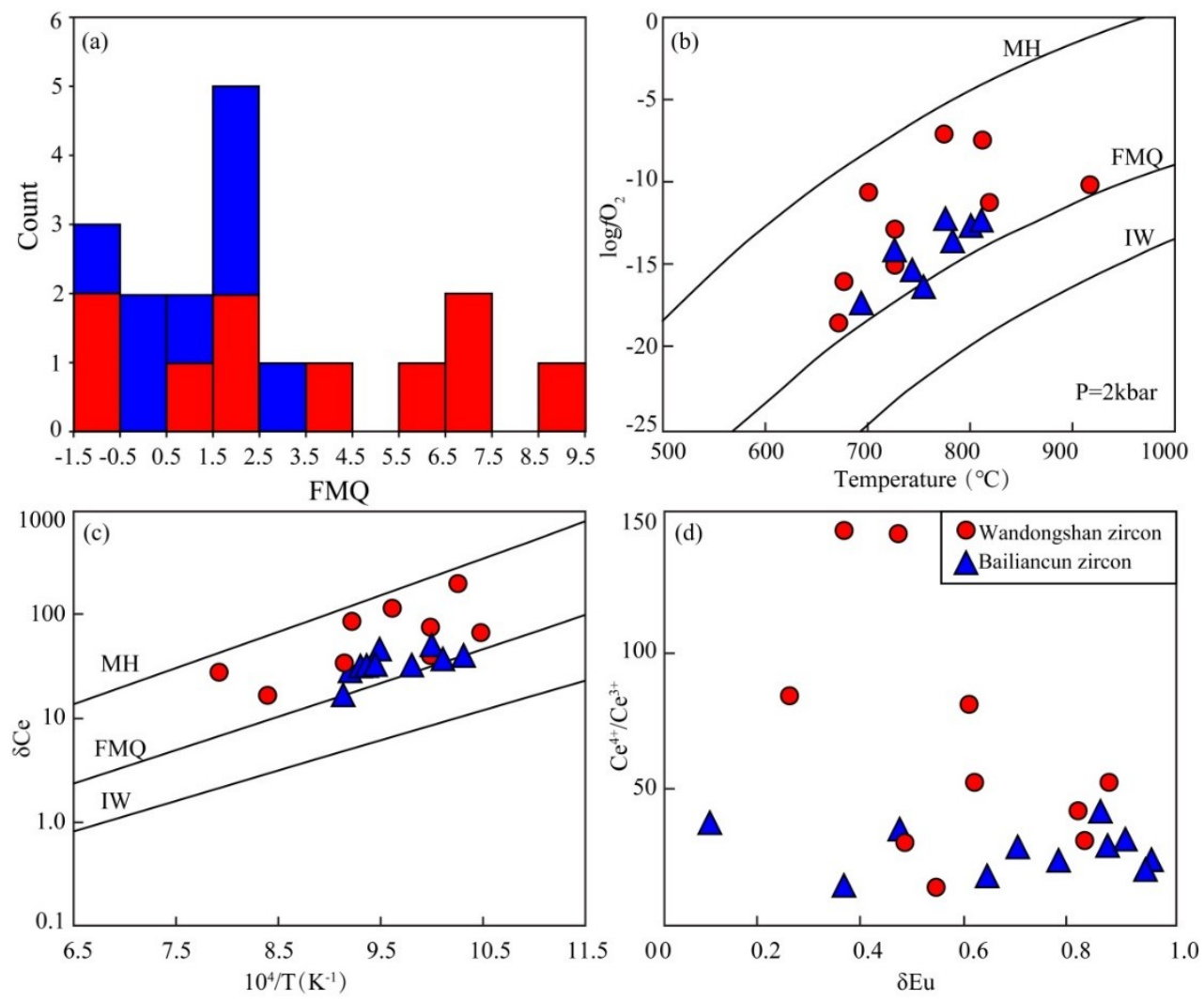

Figure 5. Magmatic oxidation state of intrusions from the Wandongshan and Bailiancun district, estimated from zircon. (a) Magma oxidation state of the Wandongshan and Bailiancun porphyries [41]; (b) Zircon $\log \mathrm{fO}_{2}$ vs. temperature; (c) linear relations for zircon Ce anomaly vs. 104 $/ \mathrm{T}$; (d) zircon $\mathrm{Ce}^{4+} / \mathrm{Ce}^{3+}$ vs. $\delta \mathrm{Eu}[44]$. MH: magnetite-hematite buffer curve; NNO: nickel-nickel oxide buffer curve; FMQ: fayalite-magnetite-quartz buffer curve; IW: iron-wustite.

\section{Discussion}

As mentioned above, the Wandongshan Au-bearing porphyries and Bailiancun barren porphyries have different physicochemical conditions (e.g., pressure, temperature, $f \mathrm{O}_{2}$, and water content). It is widely accepted that high oxidation state (high $f \mathrm{O}_{2}$ ) and high $\mathrm{H}_{2} \mathrm{O}$ content are two key factors responsible for Au mineralization [4,12,13].

\subsection{The Water Content of the Parental Magmas}

A high magmatic fluid flux ensures the exsolution of an aqueous volatile phase, which is considered as the sine qua non for magmatic hydrothermal ore-forming systems [2]. Both the Wandongshan and Bailiancun monzogranite porphyries contain amphibole phenocrysts. The amphibole phenocrysts at Wandongshan and Bailiancun are mostly euhedral in shape, and are characterized by embayed textures indicative of resorption (Figure $3 \mathrm{~b}, \mathrm{f}$ ), suggesting that these amphiboles crystallized early. The presence of amphibole during the early stages of crystallization demonstrates that the parental magma at Wandongshan and Bailiancun districts are hydrous melts ( $>4 \mathrm{wt} \% \mathrm{H}_{2} \mathrm{O}$ ) at elevated pressures $[45,46]$. Furthermore, the water content of the Wandongshan parent magma are characterized by a wider range of $3.05 \pm 0.4 \mathrm{wt} \%$ to $4.11 \pm 0.4 \mathrm{wt} \%$, whereas those of the Bailiancun parent magma have a tight range of $3.46 \pm 0.52 \mathrm{wt} \%$ to $3.91 \pm 0.4 \mathrm{wt} \%$ (Table 2), which further confirmed the parental magma at Wandongshan and Bailiancun districts are relatively water-rich.

The emplacement pressure of the parental magma at Wandongshan and Bailiancun can be estimated using the Al-in-amphibole geobarometer $[25,36]$. These results show that the emplacement 
pressures of Wandongshan porphyries range from 31.5 $\mathrm{MPa}$ to $68.6 \mathrm{MPa}$, but those of Bailiancun porphyries are significantly higher, ranging from $142.3 \mathrm{MPa}$ to $192.8 \mathrm{MPa}$ (Table 2). The solubility of $\mathrm{H}_{2} \mathrm{O}$ in silicate magmas is mainly controlled by pressure and to a lesser extent by temperature [45]. The Wandongshan parent magma could reach water saturation at 31.5-70.9 $\mathrm{MPa}$ if they contain $\sim 2.5 \%$ $\mathrm{H}_{2} \mathrm{O}$ (Figure $4 \mathrm{~b}$ ). By contrast, the Bailiancun parental magma would need more water when they reach water saturation at 142.3-192.8 MPa. Therefore, it is expected that the Wandongshan parental magma will achieve water saturation easier, and the fluid exsolution would take place at $1.2-2.4 \mathrm{~km}$, which consistent with the estimated trapping depth for Stage I S-type inclusions ( $2 \mathrm{~km}$ depth under lithostatic conditions) [17].

\subsection{Magmatic Oxidation State}

The $\log \left(\mathrm{fO}_{2}\right)$ vs. T and Ce anomaly vs. $1 / \mathrm{T}$ diagrams are divided into several oxygen fugacity fields by curves, which can be used to estimate the oxidation state of the magma. The data points of the Wandongshan monzogranite porphyry are mainly plotted within the field between magnetite-hematite buffer curve (MH) and fayalite-magnetite-quartz buffer curve (FMQ), while the $f \mathrm{O}_{2}$ of the intrusions from the Bailiancun area are lower than those of the Wandongshan porphyries (Figure $5 b, c)$. This result confirms that the porphyries from the Wandongshan district are more oxidized than those the porphyries from the Bailiancun district.

Furthermore, direct measurement of $\mathrm{fO}_{2}$ also implies that the Wandongshan porphyries are more oxidized, the $\mathrm{fO}_{2}$ deduced from amphibole chemistry of the Wandongshan porphyry range from $\Delta \mathrm{NNO}+1.00$ to $\Delta \mathrm{NNO}+1.89$ (NNO is the nickel-nickel oxide oxygen buffer), slightly higher than that of the Bailiancun porphyries $(\Delta \mathrm{NNO}+0.39$ to $\Delta \mathrm{NNO}+0.67$, Figure 6a). This result is consistent with the values calculated by zircon chemistry. The estimated $f \mathrm{O}_{2}$ using zircon chemistry for the Wandongshan porphyry is $\triangle \mathrm{FMQ}+3.5$, slightly higher than that of the Bailiancun monzogranite porphyry $(\triangle \mathrm{FMQ}+1.5$; Figure $5 \mathrm{a})$. Moreover, the Wandongshan monzogranite porphyries have an average zircon $\mathrm{Ce}^{4+} / \mathrm{Ce}^{3+}$ ratio of 62.00 (Table 2), and an average zircon Ce anomaly of 76.11 (Figure 5c), much higher than those of the Bailiancun monzogranite porphyry $(23.15,30.98$, respectively). Those differences above indicate the formation of Au-bearing porphyries requires elevated $f \mathrm{O}_{2}$.
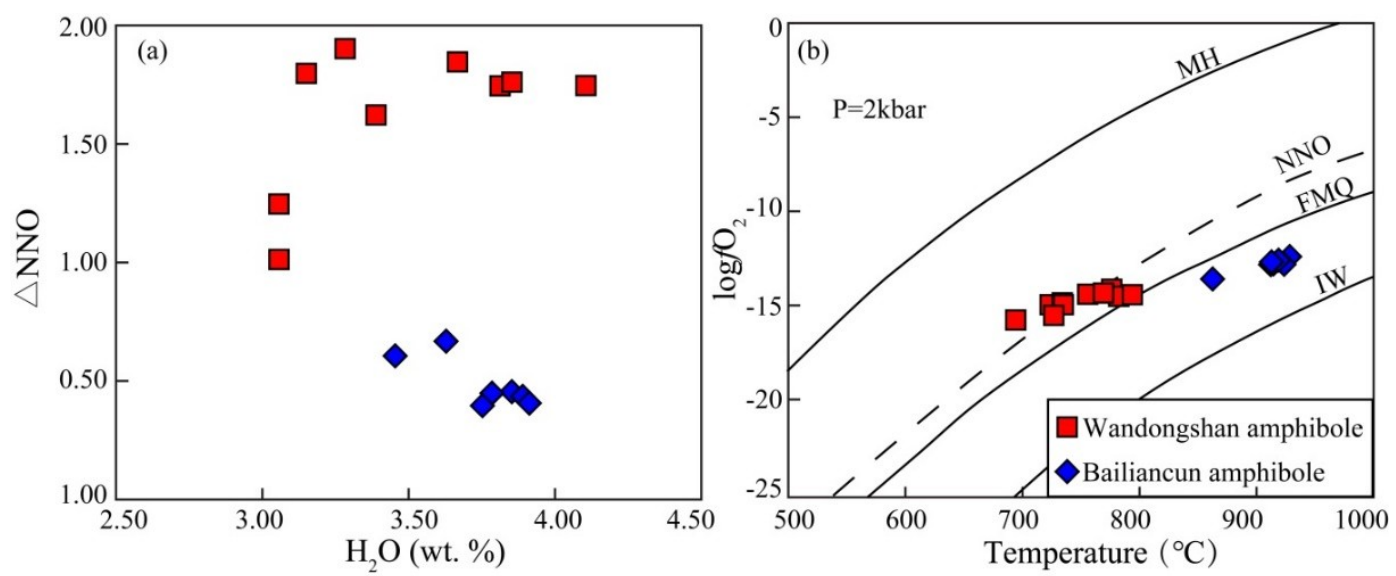

Figure 6. Magmatic oxidation state of intrusions in the Wandongshan and Bailiancun districts, estimated from amphibole compositions. (a) Magma oxidation state $(\triangle N N O)$ of Wandongshan and Bailiancun porphyries; (b) magmatic $f \mathrm{O}_{2}\left(\log f \mathrm{O}_{2}\right)$ vs. magmatic temperature. $\mathrm{MH}$ : magnetite-hematite buffer curve; NNO: nickel-nickel oxide buffer curve; FMQ: fayalite-magnetite-quartz buffer curve; IW: iron-wustite.

\subsection{Implications for Au Mineralization}

Beiya is one of the largest $\mathrm{Au}$ deposits in China, with by-products $\mathrm{Cu}, \mathrm{Fe}, \mathrm{Ag}, \mathrm{Pb}$, and $\mathrm{Zn} \mathrm{[23-25].}$ $\mathrm{Au}$ and other ore metals were derived from the alkaline melt as documented by Yang et al. [47], and the 
mineralized fluids at Beiya were mainly derived from magmatic water [16,17]. Those indicate that the Beiya alkaline melt provides ore-forming fluids and metallic elements for the formation of porphyry Au mineralization [16].

In contrast to Bailiancun porphyry, the Wandongshan porphyries are characterized by higher water content and higher $f \mathrm{O}_{2}$, but lower emplacement pressure (Table 2, Figure 7). Au solubility was investigated as a function of $f \mathrm{O}_{2}$ in sulfur-saturated silicate melts [12], indicating Au solubility in sulfur-free silicate melt increases with increasing of $f \mathrm{O}_{2}$ [48]. In addition, high $f \mathrm{O}_{2}$ favors sulfur as sulfate dissolved in the evolved magmas and suppresses magmatic sulfide precipitation $[4,7]$, which can cause sequestration of metals before they partition into the aqueous phase [10]. On the other hand, a high $\mathrm{H}_{2} \mathrm{O}$ content and a low pressure results in the Wandongshan parental magma reaching water saturation easier, because water solubility increases with increasing pressure [44], hence ensuring exsolution of aqueous volatile phases and the partitioning of Au between sulfides and silicate melt efficiently $[12,49,50]$. Therefore, melts that are more enriched in water and with a high oxidation state will be more fertile to generate Au mineralization.

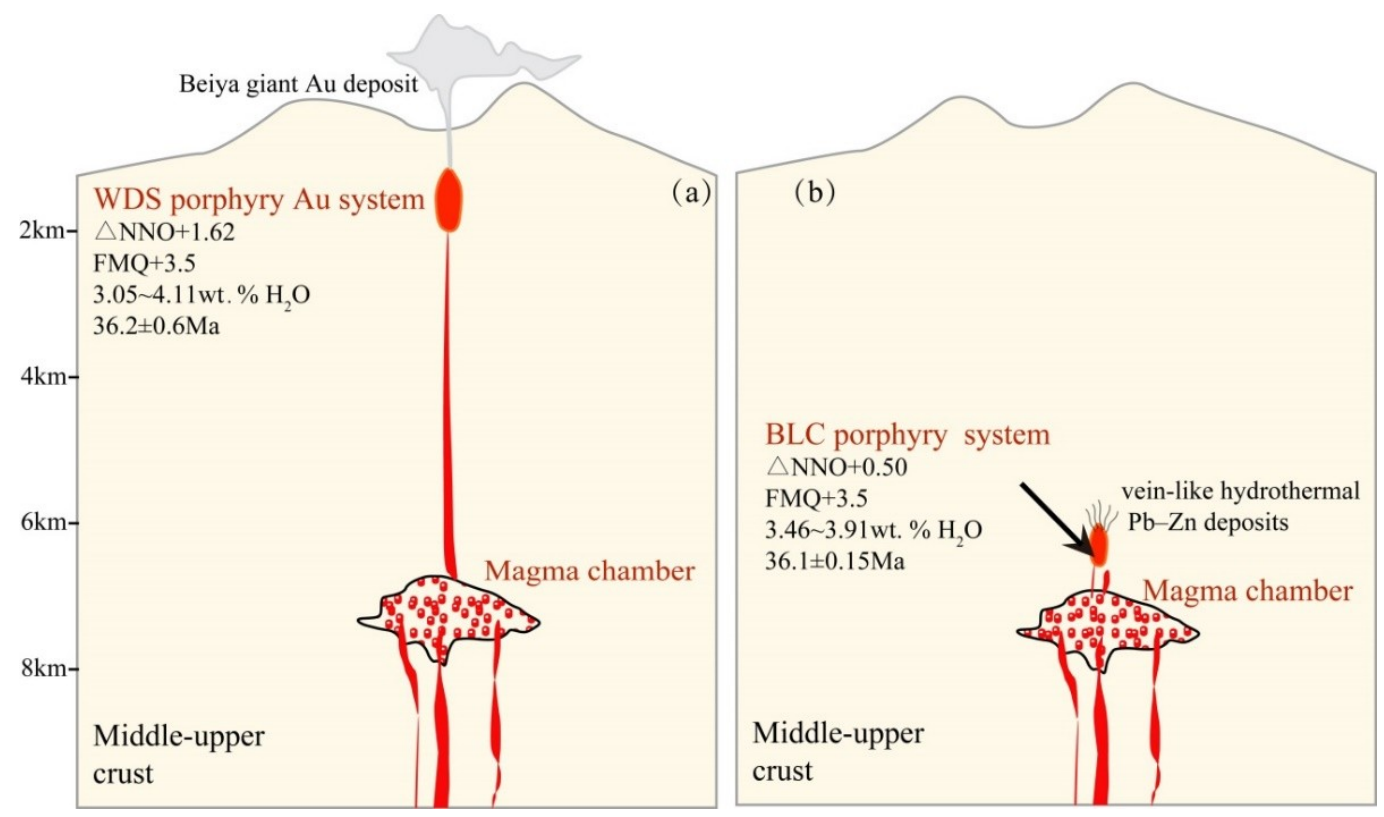

Figure 7. Cartoons illustrating the different water content, magmatic oxidation state, and emplacement depths of the parental magmas at Wandongshan (a) and Bailiancun (b), respectively. Previous studies show that the parent magma at Wandongshan (a) and Bailiancun (b) districts are derived from the same magma source [22]. This study reveals that the magma of Wandongshan experienced fluid saturation at about 1.19-2.68 km, while the magma of Wandongshan experienced fluid saturation at about $6.48-7.28 \mathrm{~km}$. The water content and magmatic oxidation state of Wandongshan parental magmas are both higher than those of the Bailiancun parental magmas.

\section{Conclusions}

Chemical compositions of zircons and amphiboles are used to evaluate the physicochemical conditions (e.g., pressure, temperature, $f \mathrm{O}_{2}$, and water content) of the parental magma. We found the water content of the Wandongshan parent magma $(\leq 4.11 \pm 0.4 \mathrm{wt} \%)$ are slightly higher than those of the parent magma at Bailiancun $(\leq 3.91 \pm 0.4 \mathrm{wt} \%)$. Furthermore, the $f \mathrm{O}_{2}$ deduced from amphibole chemistry of the Wandongshan porphyry range from $\triangle \mathrm{NNO}+1.00$ to $\triangle \mathrm{NNO}+1.89$, slightly higher than that of the Bailiancun porphyries $(\Delta \mathrm{NNO}+0.39$ to $\Delta \mathrm{NNO}+0.67)$. This result is consistent with the values calculated by zircon chemistry. The Wandongshan porphyry has higher zircon $\mathrm{Ce}^{4+} / \mathrm{Ce}^{3+}$ ratio (average of 62) and high $f \mathrm{O}_{2}$ value (average of $\triangle \mathrm{FMQ}=+3.5$ ) than those of Bailiancun porphyry (average of $\mathrm{Ce}^{4+} / \mathrm{Ce}^{3+}=23.15 ; \Delta \mathrm{FMQ}=+1.5$ ). Obviously, the Wandongshan ore-related porphyry has 
higher water content and more oxidized than the Bailiancun barren porphyry. Therefore melts that are more enriched in water and with a high oxidation state will be more fertile to form an economic hydrothermal system especially when emplaced at shallow levels.

Supplementary Materials: The following are available online at http://www.mdpi.com/2075-163X/8/10/ 441/s1, Table S1: The compositions of amphiboles from the monzogranite porphyries at Wandongshan and Bailiancun, respectively, Table S2: The Zircon trace elements in the monzogranite porphyry from Wandongshan and Bailiancun districts.

Author Contributions: X.B., L.Y. and X.G. conceived and designed the ideas; X.B. performed the experiments; X.B. and W.H. analyzed the data; X.B. prepared the original draft; X.B., L.Y., W.H. and X.G. reviewed and edited the draft.

Funding: This study was financially supported by the National Basic Research Program of China (Grant No. 2015CB452605 and 2009CB421008), the Natural Science Foundation of China (41602089), the Geological investigation work project of China Geological Survey (Grant No. 12120114013501), 111 Project of the Ministry of Education, China (Grant No. B07011) and China Postdoctoral Science Foundation (2015M581143).

Acknowledgments: We would like to thank Zhonghua He, Rui Yang and Congming Wang at Yunnan Au Corporation for their help during field work, as well as Ruigang Zhang and Mengmeng Li for their assistance with the data collection. We are grateful for constructive comments by three reviewers.

Conflicts of Interest: The authors declare no conflict of interest.

\section{References}

1. Sillitoe, R.H. Porphyry copper systems. Econ. Geol. 2010, 105, 3-41. [CrossRef]

2. Richards, J.P. High Sr/Y arc magmas and porphyry Cu-Mo-Au deposits: Just add water. Econ. Geol. 2011, 106, 1075-1081. [CrossRef]

3. Robb, L. Introduction to Ore-Forming Processes; Blackwell Publishing: Hoboken, NJ, USA, 2005; pp. 1-386.

4. Sun, W.D.; Arculus, R.J.; Kamenetsky, V.S.; Binns, R.A. Release of gold-bearing fluids in convergent margin magmas prompted by magnetite crystallization. Nature 2004, 431, 975-978. [CrossRef] [PubMed]

5. Richards, J.P. The oxidation state, and sulfur and $\mathrm{Cu}$ contents of arc magmas: Implications for metallogeny. Lithos 2015, 233, 27-45. [CrossRef]

6. Zhou, T.C.; Zeng, Q.D.; Chu, S.X.; Zhou, L.L.; Yang, Y.H. Magmatic oxygen fugacities of porphyry Mo deposits in the East Xing'an-Mongolian Orogenic Belt (NE China) with metallogenic implications. J. Asian Earth Sci. 2018, in press. [CrossRef]

7. Yang, Z.; Yang, L.Q.; He, W.Y.; Gao, X.; Liu, X.D.; Bao, X.S.; Lu, Y.G. Control of magmatic oxidation state in intracontinental porphyry mineralization: A case study from $\mathrm{Cu}(\mathrm{Mo}-\mathrm{Au})$ deposits in the Jinshajiang-Red River metallogenic belt, SW China. Ore Geol. Rev. 2017, 90, 827-846. [CrossRef]

8. Kelley, K.A.; Cottrell, E. Water and the oxidation state of subduction zone magmas. Science 2009, 325, 605-607. [CrossRef] [PubMed]

9. Yang, Z.M.; Lu, Y.J.; Hou, Z.Q.; Chang, Z.S. High-Mg diorite from Qulong in southern Tibet: Implications for the genesis of adakite-like intrusions and associated porphyry $\mathrm{Cu}$ deposits in collisional orogens. J. Petrol. 2015, 56, 227-254. [CrossRef]

10. Richards, J.P.; Spell, T.; Rameh, E.; Razique, A.; Fletcher, T. High Sr/Y magmas reflect arc maturity, high magmatic water content, and porphyry $\mathrm{Cu}-\mathrm{Mo}-\mathrm{Au}$ potential: Examples from the Tethyan arcs of Central and Eastern Iran and Western Pakistan. Econ. Geol. 2012, 107, 295-332. [CrossRef]

11. Yang, L.Q.; Deng, J.; Guo, L.N.; Wang, Z.L.; Li, X.Z.; Li, J.L. Origin and evolution of ore fluid, and Au deposition processes at the giant Taishang Au deposit, Jiaodong Peninsula, eastern China. Ore Geol. Rev. 2016, 72, 582-602. [CrossRef]

12. Li, Y.; Audetat, A. Gold solubility and partitioning between sulfide liquid, monosulfide solid solution and hydrous mantle melts: Implications for the formation of Au-rich magmas and crust-mantle differentiation. Cosmochim. Acta 2013, 118, 247-262. [CrossRef]

13. Zajacz, Z.; Candela, P.A.; Piccoli, P.M.; Walle, M.; Sanchez-Valle, C. Gold and copper in volatile saturated mafic to intermediate magmas: Solubilities, partitioning, and implications for ore deposit formation. Geochem. Cosmochim. Acta 2012, 91, 140-159. [CrossRef] 
14. Deng, J.; Wang, Q.F. Gold mineralization in China: Metallogenic provinces, deposit types and tectonic framework. Gondwana Res. 2016, 36, 219-274. [CrossRef]

15. He, W.Y.; Yu, X.H.; Mo, X.X.; He, Z.H.; Li, Y.; Huang, X.K.; Su, G.S. Genetic types and the relationship between alkali-rich intrusion and mineralization of Beiya Au-polymetallic ore field, western Yunnan province, China. Acta Petrol. Sin. 2012, 5, 1401-1412. (In Chinese)

16. He, W.Y. The Beiya Giant Au-Polymetallic Deposit: Magmatism and Metallogenic Model. Ph.D. Thesis, China University of Geosciences (Beijing), Beijing, China, 2014. (In Chinese)

17. He, W.Y.; Yang, L.Q.; Brugger, J.; McCuaig, T.C.; Lu, Y.J.; Bao, X.S.; Gao, X.Q.; Lu, Y.G.; Xing, Y.L. Hydrothermal evolution and ore genesis of the Beiya giant Au polymetallic deposit, western Yunnan, China: Evidence from fluid inclusions and H-O-S-Pb isotopes. Ore Geol. Rev. 2017, 90, 847-862. [CrossRef]

18. Xu, X.W.; Cai, X.P.; Xiao, Q.B. Porphyry Cu-Au and associated polymetallic Fe-Cu-Au deposits in the Beiya area, western Yunnan province, South China. Ore Geol. Rev. 2007, 31, 224-246. [CrossRef]

19. Bao, X.S.; He, W.Y.; Gao, X. The Beiya Gold deposit: Constrainition of water-rich magmas to mineralization. Acta Petrol. Sin. 2017, 33, 2175-2188. (In Chinese)

20. Gao, X.Q.; He, W.Y.; Gao, X.; Bao, X.S.; Yang, Z. Constraints of magmatic oxidation state on mineralization in the Beiya alkali-rich porphyry Au deposit, western Yunnan, China. Solid Earth Sci. 2017, 2, 65-78. [CrossRef]

21. Meng, X.Y.; Mao, J.W.; Zhang, C.Q.; Zhang, D.Y.; Liu, H. Melt recharge, $f \mathrm{O}_{2}-\mathrm{T}$ conditions, and metal fertility of felsic magmas: Zircon trace element chemistry of $\mathrm{Cu}$-Au porphyries in the Sanjiang orogenic belt, southwest China. Miner. Depos. 2018, 53, 649-663. [CrossRef]

22. Liu, B.; Liu, H.; Zhang, C.Q.; Mao, Z.H.; Zhou, Y.M.; Huang, H.; He, Z.H.; Su, G.S. Geochemistry and geochronology of porphyries from the Beiya Au-polymetallic orefield, western Yunnan, China. Ore Geol. Rev. 2015, 69, 360-379. [CrossRef]

23. He, W.Y.; Mo, X.X.; Yang, L.Q.; Xing, Y.L.; Dong, G.C.; Yang, Z.; Gao, X.; Bao, X.S. Origin of the Eocene porphyries and mafic microgranular enclaves from the Beiya porphyry Au polymetallic deposit, western Yunnan, China: Implications for magma mixing/mingling and mineralization. Gondwana Res. 2016, 40, 230-248. [CrossRef]

24. He, W.Y.; Mo, X.X.; He, Z.H.; White, N.C.; Chen, J.B.; Yang, K.H.; Wang, R.; Yu, X.H.; Dong, G.C.; Huang, X.F. The Geology and mineralogy of the Beiya Skarn Au Deposit in Yunnan, Southwest China. Econ. Geol. 2015, 110, 1625-1641. [CrossRef]

25. Ridolfi, F.; Renzulli, A.; Puerini, M. Stability and chemical equilibrium of amphibole in calc-alkaline magmas: An overview, new thermobarometric formulations and application to subduction-related volcanoes. Contrib. Mineral. Petrol. 2010, 160, 45-66. [CrossRef]

26. Yang, L.Q.; He, W.Y.; Gao, X.; Xie, S.X.; Yang, Z. Mesozoic multiple magmatism and porphyry-skarn Cu-polymetallic systems of the Yidun Terrane, Eastern Tethys: Implications for subduction-and transtension-related metallogeny. Gondwana Res. 2018, 62, 144-162. [CrossRef]

27. Deng, J.; Wang, Q.F.; Li, G.J.; Santosh, M. Cenozoic tectono-magmatic and metallogenic processes in the Sanjiang region, southwestern China. Earth Sci. Rev. 2014, 138, 268-299. [CrossRef]

28. Deng, J.; Liu, X.F.; Wang, Q.F.; Dilek, K.; Yang, L.Q. Isotopic characterization and petrogenetic modeling of early cretaceous mafic diking-lithospheric extension in the North China craton, eastern Asia. GSA Bull. 2017, 129, 1379-1407. [CrossRef]

29. Deng, J.; Wang, Q.F.; Li, G.J. Tectonic evolution, superimposed orogeny, and composite metallogenic system in China. Gondwana Res. 2017, 50, 216-266. [CrossRef]

30. Yang, L.Q.; Deng, J.; Qiu, K.F.; Ji, X.Z.; Santosh, M.; Song, K.R.; Song, Y.H.; Geng, J.Z.; Zhang, C.; Hua, B. Magma mixing and crust-mantle interaction in the Triassic monzogranites of Bikou Terrane, central China: Constraints from petrology, geochemistry, and zircon U-Pb-Hf isotopic systematics. J. Asian Earth Sci. 2015, 98, 320-341. [CrossRef]

31. Tapponnier, P.; Lacassin, R.; Leloup, P.H.; Shharer, U.; Zhong, D.L.; Wu, H.X.; Liu, X.H.; Ji, S.C.; Zhang, L.S.; Zhong, J.Y. The Ailaoshan-Red River metamorphic belt: Tertiary left-lateral shear between Indochina and South China. Nature 1990, 343, 431-437. [CrossRef]

32. Deng, J.; Yang, L.Q.; Li, R.H.; Groves, D.I.; Santosh, M.; Wang, Z.L.; Sai, S.X.; Wang, S.R. Regional structural control on the distribution of world-class gold deposits: An overview from the Giant Jiaodong Gold Province, China. Geol. J. 2018, 3. [CrossRef] 
33. Yang, L.Q.; Deng, J.; Wang, Z.L.; Zhang, L.; Aufarb, R.J.; Yuan, W.M.; Weinberg, R.F.; Zhang, R.Z. Thermochronologic constraints on evolution of the Linglong Metamorphic Core Complex and implications for Au mineralization: A case study from the Xiadian Au deposit, Jiaodong Peninsula, eastern China. Ore Geol. Rev. 2016, 72, 165-178. [CrossRef]

34. Deng, J.; Wang, Q.F.; Li, G.J.; Li, C.S.; Wang, C.M. Tethys tectonic evolution and its bearing on the distribution of important mineral deposits in the Sanjiang region, SW China. Gondwana Res. 2014, 26, 419-437. [CrossRef]

35. Deng, J.; Wang, C.M.; Li, G.J. Style and process of the superimposed mineralization in the Sanjiang Tethys. Acta Petrol. Sin. 2012, 28, 1349-1361. (In Chinese)

36. Schmidt, M.W. Amphibole composition in tonalite as a function of pressure; an experimental calibration of the Al-in-hornblende barometer. Contrib. Mineral. Petrol. 1992, 110, 304-310. [CrossRef]

37. Liu, Y.S.; Hu, Z.C.; Gao, S.; Günther, D.; Xu, J.; Gao, C.G.; Chen, H.H. In situ analysis of major and trace elements of anhydrous minerals by LA-ICP-MS without applying an internal standard. Chem. Geol. 2008, 257, 34-43. [CrossRef]

38. Cherniak, D.J.; Watson, E.B.; Hanchar, J.M. Rare-earth diffusion in zircon. Chem. Geol. 1997, 134, $289-301$. [CrossRef]

39. Loader, M.A.; Wilkinson, J.J.; Armstrong, R.N. The effect of titanite crystallisation on Eu and Ce anomalies in zircon and its implications for the assessment of porphyry $\mathrm{Cu}$ deposit fertility. Earth Planet. Sci. Lett. 2017, 472, 107-119. [CrossRef]

40. Watson, E.B.; Wark, D.A.; Thomas, J.B. Crystallization thermome-ters for zircon and rutile. Contrib. Mineral. Petrol. 2006, 151, 413-433. [CrossRef]

41. Leake, B.E.; Woolley, A.R.; Arps, C.E.S.; Birch, W.D.; Gilbert, M.C.; Grice, J.D.; Hawthorne, F.C.; Kato, A.; Kisch, H.J.; Krivovichev, V.G.; et al. Nomenclature of amphiboles: Report of the subcommittee on amphiboles of the International Mineralogical Association Commission on New Minerals and Mineral Names. Can. Mineral. 1997, 35, 219-246.

42. Ballard, J.R.; Palin, J.M.; Campbell, I.H. Relative oxidation states of magmas inferred from Ce(IV)/Ce(III) in zircon: Application to porphyry copper deposits of northern Chile. Contrib. Mineral. Petrol. 2002, 144, 347-364. [CrossRef]

43. Qiu, J.T.; Yu, X.Q.; Santosh, M.; Zhang, D.H.; Chen, S.Q.; Li, P.J. Geochronology and magmatic $f \mathrm{O}_{2}$ of the Tongcun molybdenum deposit, northwest Zhejiang, SE China. Miner. Depos. 2013, 48, 545-556. [CrossRef]

44. Burnham, C.W. Magmas and hydrothermal fluids. In Geochemistry of Hydrothermal Ore Deposits, 2nd ed.; Wiley: Hoboken, NJ, USA, 1979; pp. 71-136.

45. Rohrlach, B.D.; Loucks, R.R.; Porter, T.M. Multi-million-year cyclic ramp-up of volatiles in a lower crustal magma reservoir trapped below the tampakan $\mathrm{Cu}$-Au deposit by mio-pliocene crustal compression in the southern philippines. Super Porphyry Copp. Gold Depos. 2005, 2, 369-407.

46. Whitney, J.A.; Naldrett, A.J. Ore deposition associated with magmas. Econ. Geol. 1989, 4, 250.

47. Yang, L.Q.; Deng, J.; Dilek, Y.; Meng, J.Y.; Gao, X.; Santosh, M.; Wang, Da.; Yan, H. Melt source and evolution of I-type granitoids in the SE Tibetan Plateau: Late Cretaceous magmatism and mineralization driven by collision-induced transtensional tectonics. Lithos 2016, 245, 258-273. [CrossRef]

48. Bell, A.S.; Simon, A.; Guillong, M. Gold solubility in oxidized and reduced, water-saturated mafic melt. Geochim. Cosmochim. Acta 2011, 75, 1718-1732. [CrossRef]

49. Yang, L.Q.; Deng, J.; Wang, Z.L.; Guo, L.N.; Li, R.H.; Groves, D.I.; Danyushevsky, L.V.; Zhang, C.; Zheng, X.L.; Zhao, K. Relationships between Au and pyrite at the Xincheng Au deposit, Jiaodong Peninsula, China: Implications for Au source and deposition in a brittle epizonal environment. Econ. Geol. 2016, 111, 105-126. [CrossRef]

50. Humphreys, M.C.; Brooker, R.A.; Fraser, D.G.; Burgisser, A.; Mangan, M.T.; McCammon, C. Coupled interactions between volatile activity and Fe oxidation state during arc crustal processes. J. Petrol. 2015, 56, 795-814. [CrossRef]

(c) 2018 by the authors. Licensee MDPI, Basel, Switzerland. This article is an open access article distributed under the terms and conditions of the Creative Commons Attribution (CC BY) license (http:/ / creativecommons.org/licenses/by/4.0/). 